\title{
A preliminary survey of epiphytes in some tree canopies in Zambia and the Democratic Republic of Congo
}

\author{
Sven P. Batke* \\ Department of Botany, Trinity College Dublin, College Green, Navan Road, Dublin, 2, Ireland
}

\begin{abstract}
The vertical distribution of the density and richness of vascular and nonvascular epiphytes on some mature trees was studied in two $1 \mathrm{~km}^{2}$ plots in Miombo Woodland in Zambia $(\mathrm{n}=20)$ and the Democratic Republic of Congo (D.R.C.) $(\mathrm{n}=20)$. The aim was to assess the diversity of arboreal epiphytes and to investigate general distribution patterns of epiphytes along some individual mature phorophytes. Species richness was low on both sampling sites (24 in D.R.C. and nineteen in Zambia) with Orchidaceae being the richest family. Epiphyte density for both sampling plots was high with $92 \%$ of the available surface area being occupied. Lichens showed the highest density of $67.2 \%$ followed by moss $18.4 \%$, orchids $7.9 \%$ and ferns $6.5 \%$. Species richness and density showed a clear zonation within the canopy. Richness and density peaked in the upper and mid-canopy and was positively correlated with available surface area, branch aspect and to some extent bark $\mathrm{pH}$, but not with bark texture. This study demonstrated that tree canopies can harbour a diversity of epiphyte species, and the findings constitute baseline information in such environments.
\end{abstract}

Key words: Africa, density, epiphyte, Miombo, richness, tree

\section{Résumé}

Nous avons étudié la distribution verticale de la densité et de la richesse des épiphytes vasculaires et non vasculaires sur certains arbres matures de deux parcelles d'un kilomètre carré, dans une forêt à miombo en Zambie $(n=20)$ et en République Démocratique du Congo (RDC) $(\mathrm{n}=20)$. Le but était d'évaluer la diversité des épiphytes corticoles et d'analyser le schéma de distribution générale

*Correspondence: E-mail: batkesp@tcd.ie des épiphytes en même temps que quelques phorophytes individuels matures. La richesse en espèces était faible aux deux sites d'échantillonnage (24 en RDC et 19 en Zambie), et les Orchidaceae étaient la famille la plus riche. La densité des épiphytes était élevée dans les deux parcelles: 92\% de la surface disponible était occupée. Les lichens présentaient la plus forte densité avec $67.2 \%$, suivis par les mousses, $18.4 \%$, puis par les orchidées, $7.9 \%$, et les fougères, $6.5 \%$. La richesse en espèces et la densité montraient un zonage net dans la canopée. La richesse et la densité présentaient un pic dans la canopée supérieure et moyenne et étaient positivement liées à la superficie disponible, à l'aspect des branches et, dans une certaine mesure, au pH de l'écorce mais pas à sa texture. Cette étude montre que la canopée des arbres peut abriter toute une diversité d'espèces épiphytes, et ces résultats constituent une base de référence pour de tels environnements.

\section{Introduction}

Deciduous and semi-deciduous dry forests in Africa contribute substantially to the global plant diversity (Chidumayo \& Gumbo, 2010); however, little is still known about their importance to epiphytic canopy organisms. Epiphytes are vascular and nonvascular plants that live on other plants (i.e. phorophytes), such as trees, for physical support; however, they do not gain nutrient or water supply directly from the host (Kress, 1986). These organisms are major contributors to the biomass and the alpha and beta diversity of a forest (Hsu, Horng \& Kuo, 2002), provide a diverse range of habitats and food resources for other organisms (Davidson, 1988; Nadkarni \& Matelson, 1989; Fischer \& Araujo, 1995) and regulate mineral (Pike, 1978) and nutrient cycling (Díaz et al., 2010). Regardless of their importance, research on vascular and in particular nonvascular epiphytes in Africa 
remains sporadic. Early studies include work done by Sanford (1968, 1969), Johansson (1974, 1978), Sermolli (1985), Akinsoji (1990) and Barthelemy (1992). Later work comprises that of Kürschner (1995), Zapfack et al. (1996), Biedinger \& Fischer (1996), Schaijes \& Malaisse (2001), Nkongmeneck, Lowman \& Atwood (2002), Mucunguzi (2007), Nyandwi (2008), Zapfack \& Engwald (2008), Addo-Fordjour et al. (2009), Droissart et al. (2011, 2012).

Most of these studies, however, focused on specific epiphytic groups (e.g. pteridophytes and orchids) with the only exception being Biedinger \& Fischer's (1996) study on vascular and nonvascular epiphytes in Rwanda and Zaïre [now known as Democratic Republic of Congo (D. R.C.)]. Besides, other studies only mentioned epiphytes briefly as part of a wider vegetation survey (Poulsen et al., 2005; Hemp, 2006). This deficiency and/or absence of epiphyte research in most African countries might be associated with the generally low epiphyte diversity observed in many studies. For example, some epiphytic plant species from the families Bromeliaceae and Cactaceae are partially or entirely absent in Africa (Zapfack \& Engwald, 2008).

In addition, it has become evident that the biomass, species richness and composition of some epiphytes change with height in the canopy (Johansson, 1974; Gauslaa, Lie \& Ohlson, 2008; Fritz, 2009). Moreover epiphytes are highly dependent on their host for physical support; their spatial and physical segregation from terrestrial resources constrains them in any means to a more dependent lifestyle. Bark texture, the instability of the substrate, nutrient availability of the suspended soil, atmospheric nutrient, litter fall, leaching, branch type and aspect can play key roles in their diversity, abundance and distribution (Marmor, Tõrra \& Randlane, 2010). Although many important abiotic and biotic factors that affect epiphyte distributions in tree canopies have been identified, there still appears to be a sparse number of studies in Africa that assess these trends.

Vascular and nonvascular epiphytes in Zambia and southern D.R.C. have received little research attention, making this study an important contributor to epiphyte research in Africa. The two woodland sites were chosen because of their comparable woodland structure, distribution of mature trees within the sample area and topography. This study aimed (i) to assess the vascular and nonvascular epiphytic diversity on selected mature trees of two woodland plots, (ii) to compare the epiphyte distribution, diversity and abundance (iii) and to investigate the vertical distribution, abundance and density of different groups of epiphytes along an elevation gradient of individual host trees (phorophytes).

\section{Materials and methods}

\section{Study area}

The two 1-km² woodland plots were located at the Nsobe Game Ranch (latitude $13^{\circ} 22^{\prime} 39.90^{\prime \prime} \mathrm{S}$, longitude $28^{\circ} 45^{\prime}$ $\left.02.82^{\prime \prime E}\right) 60 \mathrm{~km}$ south of Ndola and approximately $60 \mathrm{~km}$ north of Kapiri Mposhi in Zambia, and the Kamoa Exploration Camp (latitude $10^{\circ} 76^{\prime} 81.92^{\prime \prime}$, longitude $25^{\circ}$ $\left.25^{\prime} 42.73^{\prime \prime E}\right)$ approximately $25 \mathrm{~km}$ west of the town of Kolwezi and about $270 \mathrm{~km}$ from the provincial capital Lubumbashi, D.R.C. (Fig. 1). The woodlands were defined as open, mesic Miombo and transitional Miombo dry forest (Chidumayo \& Gumbo, 2010). The topography of both sample sites was slightly undulated with a mean elevation of $1363 \mathrm{~m}$. At the Zambian site, mean annual temperature was $24^{\circ} \mathrm{C}$, with a mean annual precipitation of $1000 \mathrm{~mm}$ and a mean annual humidity of $61 \%$ (Phiri, 2005). At the D.R.C. site, mean annual temperature was $28^{\circ} \mathrm{C}$ with a mean annual precipitation of $1270 \mathrm{~mm}$ and a mean annual humidity of $67 \%$ (INPL, 2010). To capture the flowering period of many species and because of logistical time constrains, data were collected at the end of the rainy season between January and March 2010 .

\section{Sampling}

A total number of 40 mature trees were sampled. The twenty trees per plot were chosen according to physical and morphological properties, abundance and climbing accessibility. A total number of three tree species from two genera were sampled. The twenty trees in Nsobe constituted Brachystegia longifolia Benth. $(\mathrm{n}=5)$ and Brachystegia boehmii Taub. $(\mathrm{n}=15)$ species, whereas the other twenty trees in Kamoa were represented by Marquesia macroura Gilg. $(\mathrm{n}=20)$ species.

Data were obtained using single-rope techniques, dualrope techniques and adopted industrial climbing techniques. These systems have been extensively used in canopy science and have been described in more detail elsewhere (Lowman \& Rinker, 2004; Batke, 2012). Data such as branch height from the upper surface of the branch to the ground, circumference and aspect of the 


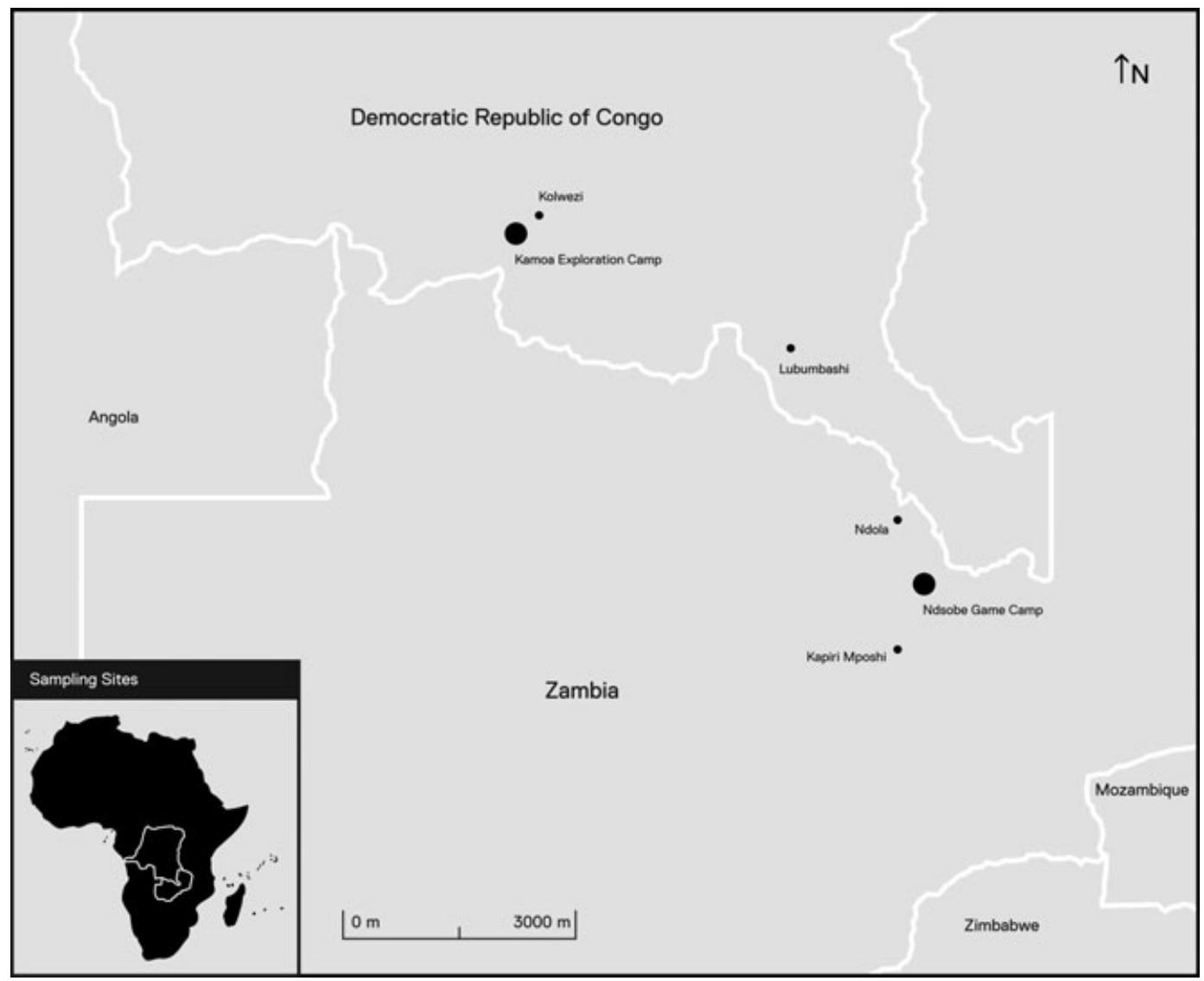

Fig 1 Sampling site in Nsobe Game Camp, Zambia (latitude 1322'39.90"S, longitude $28^{\circ} 45^{\prime} 02.82^{\prime \prime}$ ), and the Kamoa Exploration Camp, D.R.C. (latitude $10^{\circ} 76^{\prime} 81.92^{\prime \prime}$ S, longitude $25^{\circ} 25^{\prime} 42.73^{\prime \prime}$ ). Sites are marked with a large black dot. Small dots symbolize nearby towns (see text for further description)

branch, branch and bole length, diameter at breast height (DBH) and total height of the tree, bark texture, species percentage cover and bark $\mathrm{pH}$ were collected for every phorophyte. Variables were decided upon following considerations from the literature (Sanford, 1968; Johansson, 1978; Gradstein et al., 2003; Lowman \& Rinker, 2004). Only species data for bryophytes, lichens, orchids and ferns were collected.

The bole was divided into four different aspects (north, east, south and west). Total percentage cover for every species at every aspect was estimated. Because some of the epiphytes had multilayered growth patterns, the percentage abundance sometimes exceeded 100\%. Percentage cover was estimated to the nearest $5 \%$, with $5 \%$ being the lowest. Total height of the bole was measured, and DBH was obtained at a standard height of $137 \mathrm{~cm}$. A $10 \mathrm{~g}$ bark sample was collected for later $\mathrm{pH}$ analysis.
The texture of the bark was recorded for every aspect, that is, (i) smooth, (ii) flaky, (iii) lightly fissured and (iv) deeply fissured.

Every branch with a circumference $>35 \mathrm{~cm}$ was sampled. To reduce the damage to the tree that might have occurred when following standard procedure (Gradstein et al., 2003), smaller branches were not sampled. In addition, damaged and infected branches were excluded from the collection process. The total length of every branch was measured, and circumference was obtained from the middle of every branch. Moreover, the height from the top edge of the branch to the ground was measured using a tape measure. Branch aspect was determined by following the general direction of the branch using a standard compass $(1=\mathrm{N} / \mathrm{NE}, 2=\mathrm{E} / \mathrm{SE} / \mathrm{W} / \mathrm{NW}$, $3=\mathrm{S} / \mathrm{SW}$ ). Species percentage cover and bark texture were recorded as described earlier. In addition, the type 
of branch, that is, primary, secondary, etc., was recorded for later analysis. All species were collected and later identified to genus/species level.

\section{Data analysis}

For the analysis, individual phorophytes were divided into five dynamic height-zones. Zone 1 (D) consisted of the bole. Zones 2-5 were classed into percentages, each zone being $25 \%$ (i.e. all branches $=100 \%$ ). Zone 2 accounted for all branches between $0 \%$ and $25 \%$, zone 3 between $25 \%$ and $50 \%$, zone 4 between $50 \%$ and $75 \%$ and zone 5 between $75 \%$ and 100\%. Branches below the 'branch-canopy' were added to zone 2 (i.e. all minus values). Total surface area of every bole and branch was calculated according to Eq. 1 as:

$\mathrm{Si}=\pi d h$

where $\mathrm{Si}$ is the total surface area, $d$ the diameter and $h$ the total length of the branch/bole. This formula assumes that the branch/bole is circular in section (Swank \& Schreuder, 1974). Bole and branch areas for every individual phorophyte were summed to calculate the total available surface area. The same was done for every zone.

Species surface density was calculated for every site, phorophyte, zone and species of epiphyte using surface area and estimated percentage cover according to Eq. 2 as:

$\rho_{A}=A(n) / 100$

where $\rho_{A}$ is the species surface density, $A$ the total available surface area and $n$ the summed estimated percentage cover for all epiphytes, divided by 100. All percentage cover data were adjusted previous to implementation, that is, proportionally adjusted for all branches, which allowed confining the sample size to the actual available area. Species were then divided into four groups, that is, fern, lichen, moss and orchid.

Species diversity between the sites was calculated using Shannon's Diversity index, Simpson's Diversity index and Pielou Evenness index. The vegetation data were explored using Nonmetric Multidimensional Scaling (NMS) ordination and vegetation clustering (Mccune \& Mefford, 2011). Moreover, a Spearman's rank correlation was used to obtain significant levels for the nonparametric measurements identified by the NMS (Velleman \&
John, 1996). The ordination and nonparametric correlation analyses were carried out separately between the two sample sites because the clustering suggested a strong independence of the vegetation types in Zambia and the D.R.C. However, the ordination visualization was performed with the combined data set. For the analysis, five factors were tested including phorophyte DBH, height of the tree, surface area, bark $\mathrm{pH}$ and number of branches. Altitude was not included in the analysis because it would have reduced the explanatory power of other variables (Wolf, 2005).

Density, group and zone were compared using a balanced analysis of variance (ANOVA). Species number and density association between different zones and sites was performed using regression analysis (Minitab, 2010). Finally, area and density calculations were carried out in Microsoft Excel (with Microsoft excel spreadsheet).

\section{Results}

\section{Composition and diversity}

A total of 29 species of epiphytes from twelve families were identified (Table 1) including three species of fern, ten species of lichen, five species of moss and eleven species of orchids. Species differences between sites (Table 1) and group differences between sites (Table 2) were observed, the D.R.C. being the most species-rich site with $\mathrm{n}=24$ and $\mathrm{n}=19$ for Zambia. Ferns and lichens were equally rich on both sampling sites $(\mathrm{n}=8)$. However, mosses and orchids had a higher richness at the D.R.C. site (Table 2). Species diversity and evenness did not significantly differ $(\mathrm{df}=38, P<0.05)$ between sampling sites. Both sites showed a similar overall species diversity and evenness (Table 3).

\section{Host morphology}

Trees within and between sampling sites varied significantly in their morphology (Table 4$)(\mathrm{df}=38, P<0.05)$. The trees sampled in Zambia were taller than those in the D.R.C., but they had a smaller mean DBH (1.83 and $2.13 \mathrm{~m}$, respectively). Mean number of branches in Zambia was lower $(\mathrm{n}=20.2)$ when compared to the D.R.C. $(\mathrm{n}=29.0) \quad(\mathrm{df}=38, P<0.05)$. Total available phorophyte surface area in both sites was $332.9 \mathrm{~m}^{2}$ of which $306.2 \mathrm{~m}^{2}(92 \%)$ was occupied by epiphytes. There were only marginal differences between the sites, with 
Table 1 Species list for both sample sites

\begin{tabular}{|c|c|c|c|c|}
\hline \multirow[b]{2}{*}{ Epiphyte species } & \multirow[b]{2}{*}{ Family } & \multirow[b]{2}{*}{ Group } & \multicolumn{2}{|c|}{ Present/Absent } \\
\hline & & & D.R.C. & Zambia \\
\hline Nephrolepis undulata J.Sm. & Oleandraceae & Fern & $\mathrm{X}$ & \\
\hline Pleopeltis excavata (Willd.) Sledge & Polypodiaceae & Fern & $\mathrm{X}$ & $\mathrm{X}$ \\
\hline Pyrrosia schimperiana (Kuhn) Alston & Polypodiaceae & Fern & & $\mathrm{X}$ \\
\hline Bryoria fuscesens Gyeln. & Parmeliaceae & Lichen & $\mathrm{X}$ & $\mathrm{X}$ \\
\hline Cladonia spp. ${ }^{\mathrm{a}}$ & Cladoniaceae & Lichen & $\mathrm{X}$ & \\
\hline Diploicia canescens (Dickson) A. Massal & Physciaceae & Lichen & $\mathrm{X}$ & $\mathrm{X}$ \\
\hline Lecanora chlarotera Nyl. & Lecanoraceae & Lichen & & $\mathrm{X}$ \\
\hline Unidentified & & Lichen & $X$ & $\mathrm{X}$ \\
\hline Parmelia perlata (L.) Ach. & Parmeliaceae & Lichen & $\mathrm{X}$ & $\mathrm{X}$ \\
\hline Phaecophyscia orbicularis (Neck.) Moberg & Physciaceae & Lichen & $\mathrm{X}$ & $\mathrm{X}$ \\
\hline Pseudevernia furfuracea (L.) Zopf & Parmeliaceae & Lichen & $\mathrm{X}$ & $\mathrm{X}$ \\
\hline Usnea florida (L.) Weber ex F.H. Wigg & Parmeliaceae & Lichen & & $\mathrm{X}$ \\
\hline Usnea subfloridana Stirt. & Parmeliaceae & Lichen & $\mathrm{X}$ & \\
\hline Campylopus robillardei var. perauriculatus (Broth.) & Dicranaceae & Moss & $\mathrm{X}$ & $\mathrm{X}$ \\
\hline Fabronia pilifera Hornsch. & Fabroniaceae & Moss & $\mathrm{X}$ & $\mathrm{X}$ \\
\hline Macromitrium sulcatum (Hook.) Brid. & Orthotrichaceae & Moss & $\mathrm{X}$ & \\
\hline Octoblepharum albidum Hedw. & Calymperaceae & Moss & $\mathrm{X}$ & $\mathrm{X}$ \\
\hline Schlotheimia ferruginea Bridel. & Orthotrichaceae & Moss & $\mathrm{X}$ & \\
\hline Bulbophyllum brevidenticulatum De Wild. & Orchidaceae & Orchid & $\mathrm{X}$ & \\
\hline Calyptrochilum christyanum (Rchb. f.) Summerh. & Orchidaceae & Orchid & & $\mathrm{X}$ \\
\hline Cyrtorchis crassifolia Schltr. & Orchidaceae & Orchid & $\mathrm{X}$ & \\
\hline Polystachya fusiformis Lindl. & Orchidaceae & Orchid & $\mathrm{X}$ & \\
\hline Polystachya heckmanniana Kraenzl. & Orchidaceae & Orchid & $\mathrm{X}$ & $\mathrm{X}$ \\
\hline Polystachya modesta Rchb. f. & Orchidaceae & Orchid & $\mathrm{X}$ & $\mathrm{X}$ \\
\hline Polystachya vaginata Summerh. & Orchidaceae & Orchid & $\mathrm{X}$ & \\
\hline Polystachya kermesina Kraenzl. & Orchidaceae & Orchid & $\mathrm{X}$ & \\
\hline Rangaeris muscicola (Rchb. f.) Summerh. & Orchidaceae & Orchid & $\mathrm{X}$ & $\mathrm{X}$ \\
\hline Tridactyle bicaudata Schltr. & Orchidaceae & Orchid & & $\mathrm{X}$ \\
\hline Tridactyle translucens Summerh. & Orchidaceae & Orchid & $\mathrm{X}$ & $\mathrm{X}$ \\
\hline Total & & & 24 & 19 \\
\hline
\end{tabular}

Species marked with an ' $\mathrm{X}$ ' indicates whether the species was present.

a Only identified to genus.

Table 2 Density (\%) and number of total epiphyte species divided into groups for both sample sites

\begin{tabular}{lccccc}
\hline & \multicolumn{2}{l}{ Density $(\%)$} & & \multicolumn{2}{l}{ No. species } \\
\cline { 2 - 3 } \cline { 5 - 6 } Group & D.R.C. & Zambia & & D.R.C. & Zambia \\
\hline Fern & 7.63 & 5.35 & & 2 \\
Lichen & 71.26 & 62.89 & & 8 & 8 \\
Moss & 13.40 & 23.68 & & 5 & 3 \\
Orchid & 7.68 & 8.07 & & 6 \\
Total & 100 & 100 & & 24 & 19 \\
\hline
\end{tabular}

Zambian epiphytes occupying a total of $44.7 \%$ and D.R. C. epiphytes $47.3 \%$ of the total available area (Table 5). Mean surface area varied between different canopy zones
(Fig. 2). Phorophytes in the D.R.C. had a higher surface area in zone 2 , followed by a gradual reduction towards the upper and the lower zones. In Zambia, however, phorophytes had more surface area in the mid-canopy, that is, zones three and four.

Distribution, richness and density

Epiphytic groups, that is, fern, lichen, moss and orchids, varied only marginally in density between sites $\left(F_{1,199}=\right.$ $0.06, P>0.05)$ but significantly between groups within sites (Table 2). The group with the highest density on both sites was lichen (a total of $67.2 \%$ ), with species such as Phacophyscia orbicularis, Parmelia perlata and 
Table 3 Average species richness (S), evenness (E), Shannon's Diversity index (H) and Simpson's Diversity index (D') between D.R.C. and Zambia

\begin{tabular}{llllllllll}
\hline Site & Mean & SD & Sum & Min. & Max. & S & E & $H$ & $D^{\prime}$ \\
\hline D.R.C. & 6.878 & 10.56 & 199.4 & 0 & 32.45 & 13.6 & 0.884 & 2.298 & 0.8856 \\
Zambia & 4.498 & 7.537 & 130.4 & 0 & 23.05 & 11.6 & 0.877 & 2.137 & 0.8648 \\
\hline
\end{tabular}

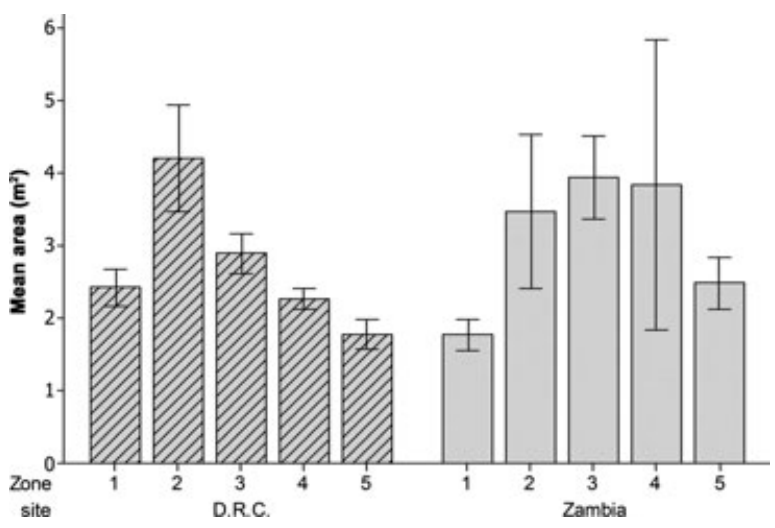

Fig 2 Mean phorophyte surface area and standard error between different zones of Zambia and the D.R.C.

Diploicia canescens being the most common varieties. Moss had the second highest density (18.4\%) followed by orchids $(7.9 \%)$ and ferns $(6.5 \%)$.

Density of all groups in zone 1 was relatively low but exponentially increases in zones two, three and four where it then decreases in zone 5 again (Fig. 3). Significant differences between groups within and between zones were observed (fern: $F_{4,199}=2.41, \quad P<0.05$; lichen: $F_{4,199}=20.67, P<0.05$; moss: $F_{4,199}=4.48$, $P<0.05$; orchids: $\left.F_{4,199}=4.72, P<0.05\right)$. Moreover, species richness showed a similar pattern to species density. Richness was highest in zones three and four and lowest in zones one, five and two (not shown).

Total available surface area between different zones was significantly correlated with overall changes in species density and species richness $\left(F_{3,6597}=233\right.$,
$\left.R^{2}=9.6, P<0.05\right)$. Also, density and species richness were positively correlated at both sites (Tables 6 and 7), but differences in zones were observed (zone 1: $F_{1.38}=13.73, P<0.05$; zone $2: F_{1.38}=0.24, P>0.05$; zone 3: $F_{1,38}=11.70, P<0.05$; zone $4: F_{1,38}=12.39$, $P<0.05$; zone 5: $\left.F_{1,38}=11.70, P>0.05\right)$.

Other components

Figure 4 shows that bark $\mathrm{pH}$ and the number of branches were the most important variables. In the D.R. C., the ordination coefficient (two dimensions) indicated that axis 1 accounted for the highest similarity (Table 8). At this site, the physical properties of the phorophyte (i.e. number of branches, area, DBH and height) showed significant $\left(P<0.05, r_{\mathrm{s}}=0.447\right)$ positive correlation. Axis 2 had no significant correlation $\left(P>0.05, r_{\mathrm{s}}=0.447\right)$ to any of the variables. For the Zambian site composition data, the NMS recommended a three-dimensional solution (Table 9). However, axis 1 was not statistically significant following Monte Carlo procedure $(P>0.05)$ and was therefore excluded from further analysis (Kent, 2012). Bark pH on axis 2 and number of branches on axis 3 explained most of the similarity of the epiphyte composition between the phorophytes in Zambia. However, the results were not statistically significant $\left(P>0.05, r_{\mathrm{s}}=0.447\right)$ (Table 9).

Bark $\mathrm{pH}$ was significantly different between Zambia and the D.R.C. $(\mathrm{df}=38, \quad \mathrm{P}<0.05)$. Phorophytes in Zambia had a mean $\mathrm{pH}$ of $5.66 \pm 0.05$, whereas phorophytes in the D.R.C. had a lower mean $\mathrm{pH}$ of $3.37 \pm$ 0.03. Species richness was significantly negative correlated

Table 4 Mean differences in phorophyte traits between Zambia and the D.R.C.

\begin{tabular}{|c|c|c|c|c|c|c|}
\hline & \multicolumn{3}{|l|}{ Zambia } & \multicolumn{3}{|l|}{ D.R.C. } \\
\hline & $\mathrm{DBH}(\mathrm{m})$ & Height (m) & No. branches & $\mathrm{DBH}(\mathrm{m})$ & Height $(\mathrm{m})$ & No. branches \\
\hline Mean & 1.83 & 15.68 & 20.20 & 2.13 & 14.25 & 29.00 \\
\hline SE & 0.10 & 0.50 & 1.71 & 0.07 & 0.33 & 1.14 \\
\hline
\end{tabular}

Significant values at $P<0.05$ are given in bold. 
Table 5 Total available, occupied and unoccupied area per site based on species density

\begin{tabular}{lccl}
\hline & $\begin{array}{l}\text { Zambia } \\
\mathrm{m}^{2}(\%)\end{array}$ & $\begin{array}{l}\text { D.R.C. } \\
\mathrm{m}^{2}(\%)\end{array}$ & $\begin{array}{l}\text { Total } \\
\mathrm{m}^{2}(\%)\end{array}$ \\
\hline Available area & $161.3(48.5)$ & $171.5(51.5)$ & $332.9(100)$ \\
Occupied area & $148.7(44.7)$ & $157.5(47.3)$ & $306.2(92.0)$ \\
Unoccupied area & $12.6(3.9)$ & $14.0(4.0)$ & $26.7(8.0)$ \\
\hline
\end{tabular}

with bark $\mathrm{pH}$ when analysed with the combined data set $\left(F_{1,38}=6.18, R^{2}=13.99, P<0.05\right)$, but species surface density was not $\left(F_{1,38}=0.05, R^{2}=0.1, P>0.05\right)$.

At branch level, bark texture varied only slightly between different phorophytes with a greater range at the D.R.C. site. Lightly fissured was the most frequent bark texture on both sites $(83.3 \%)$, followed by deeply (7.2\%), smooth (5.3\%) and flaky (4.2\%) bark. Though, neither species density nor species richness was statistically correlated with bark texture at the sites (Tables 6 and 7). The branch aspect was positively correlated with epiphyte richness at the Zambian site and negatively at the D.R.C. site (Tables 6 and 7). Richness was highest on north-west-facing branches in Zambia and north-east-facing branches in the D.R.C. The lowest richness on both sites was observed on north-facing branches. Density showed no correlation with branch aspect.

\section{Discussion}

A total of 29 species of epiphytes were encountered with Orchidaceae being the most diverse family. This number does not seem particularly high when compared to epiphyte studies in tropical parts of the world (Gentry, 1982; Benzing, 1990), but is comparable with studies undertaken in other dry forests elsewhere (Werner \& Gradstein, 2009) and tropical rainforest in Africa (AddoFordjour et al., 2009). Biedinger \& Fischer (1996), for example, found in two dry forests in Rwanda three species of orchids, 24 species of lichen and no species of fern and moss. The observed low epiphyte diversity along gradients of increased aridity is thought to be a reflection of the epiphytes specialization to moist environments and the lower nutrient capital available to the epiphytes in dry forests (Sanford, 1968; Benzing, 1990). Although the diversity is commonly reduced at dry and highly exposed sites, the abundance and density of epiphytes is often higher (Benzing, 1987, 1990). All sampled phorophytes in Zambia and the D.R.C., for example, had over $90 \%$ of epiphyte cover. Most of the high cover was attributed to moss and lichen species (approximately 85\%), which could be a reflection of their colonial life form, that is, turf, mats and cushions (Sillett \& Antoine, 2004). Vascular epiphytes (i.e. orchids and ferns) on the other hand are more perpendicular in their growing habit and often require less phorophyte surface area per individual than nonvascular epiphytes. Moreover, their mode of reproduction (sexual and asexual) (Löbel \& Rydin, 2009) and affinity to higher solar radiation (Purvis, 2000) allow nonvascular epiphytes to occupy a wider niche, whereas vascular epiphytes are more niche restricted by physiological tolerance limits (Werner \& Gradstein, 2008). For example, epiphytes sensitive to drought, such

Fig 3 Surface density of epiphytic group zones in Zambia and the D.R.C.

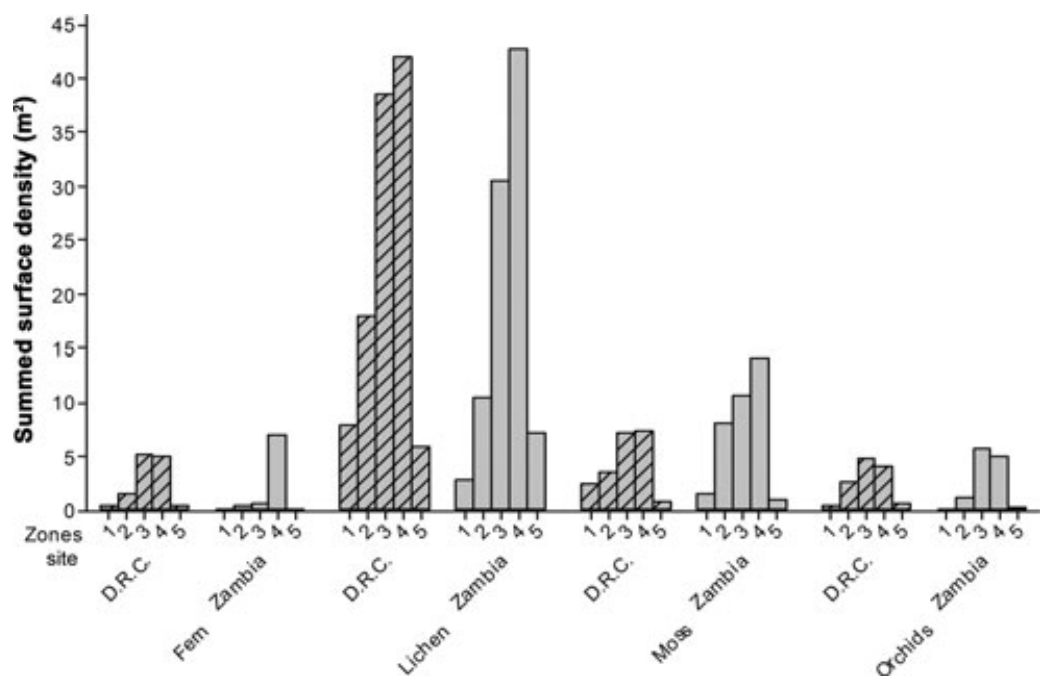


Table 6 Spearman's rank correlation coefficient for branches in Zambia

\begin{tabular}{lclll}
\hline & Texture & Aspect & Density & Richness \\
\hline Texture & 1 & & & \\
Aspect & -0.926 & 1 & & \\
Density & -1.831 & 0.189 & 1 & \\
Richness & -0.905 & $\mathbf{2 . 0 2 1}$ & $\mathbf{2 . 3 9 9}$ & 1 \\
\hline
\end{tabular}

The critical value for a two-tailed Student's $t$-test at $\alpha 0.05$ was 1.96. Significant values are given in bold.

Table 7 Spearman's rank correlation coefficient for branches in the D.R.C.

\begin{tabular}{lccll}
\hline & Texture & Aspect & Density & Richness \\
\hline Texture & 1 & & & \\
Aspect & 1.697 & 1 & & \\
Density & -1.298 & -1.822 & 1 & \\
Richness & -0.899 & $\mathbf{- 2 . 6 2 1}$ & $\mathbf{9 . 2 0 9}$ & 1 \\
\hline
\end{tabular}

The critical value for a two-tailed Student's $t$-test at $\alpha 0.05$ was 1.96. Significant values are given in bold.

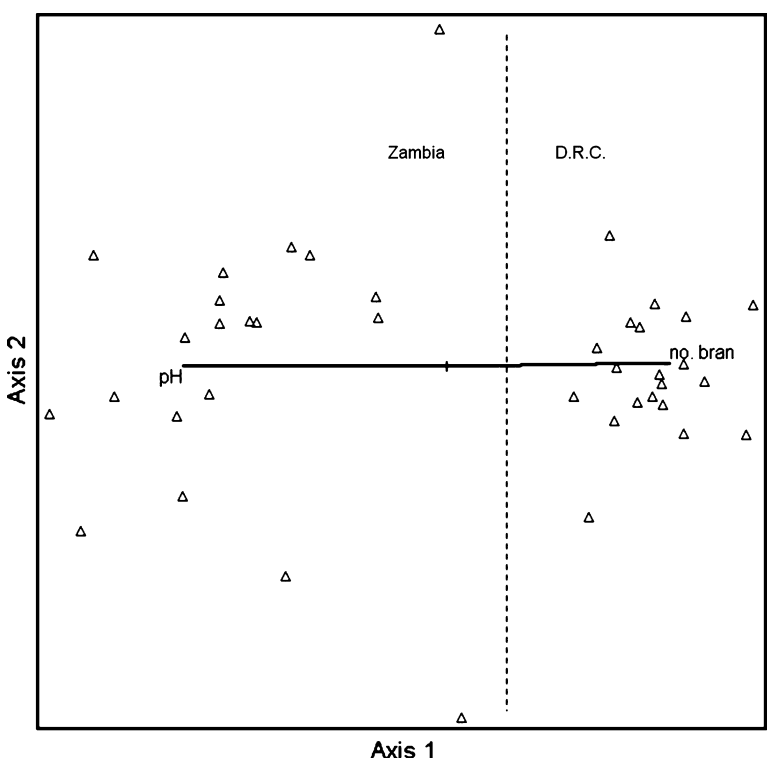

Fig 4 Nonmetric Multidimensional Scaling (NMS) ordination plot for Zambia and the D.R.C. combined. Per cent of cumulative variance in distance matrix was $R^{2}=0.807$ and $R^{2}=0.931$ for axes one and two, respectively. Bark $\mathrm{pH}(\mathrm{pH})$ and number of branches (no. bran) were the most important environmental variables in explaining the species composition between sites. Bark $\mathrm{pH}$ was more important at the Zambian site, whereas number of branches was a stronger force at the D.R.C. site as many orchids, were more frequently encountered on intermediate exposed branches (S.P. Batke, Personal observation).

The difference in epiphyte richness between the two sample sites could be the result of four processes. First, epiphytes at the D.R.C. site grew in more moist conditions compared to epiphytes at the Zambian site. Second, phorophytes in the D.R.C. had a larger canopy with more branches, particularly in the lower canopy (Fig. 2 and Table 4). Third, the woodland at the Zambian site was characterized by more disturbances, possibly resulting in a more open vegetation, higher light irradiation and lower humidity (Muñoz et al., 2003). Finally, Wolf (2005) pointed out that the distance between the sample sites could explain $20-30 \%$ of the variance in epiphyte composition and diversity between sample sites. Although different species of host trees have been investigated, the effect of epiphyte-host specificity is most certainly negligible (Callaway et al., 2002). The NMS ordination (Fig. 4) suggested that the site variation in epiphyte composition and richness in the D.R.C. was driven by the physical properties of the phorophyte (Table 8). However, at the Zambian site, the variation in epiphyte composition between individual phorophytes could not be explained by the measured variables (Table 9). It is more than likely that all of the abovementioned processes affect the difference in epiphyte composition between the sites; however, the results are inconclusive. Further studies should therefore explore additional factors including nutrient availability to the epiphyte, microclimatic climate variations within the phorophyte, competition, epiphyte dispersal and geographical relationships between sample sites.

At both sample sites, epiphytes showed a clear zonation in the canopy with density and richness being highest at mid- and upper canopy (Fig. 3). This trend is similar to that found in other studies (Wolf, 1994; Schuettpelz \& Trapnell, 2006) but contradicts Addo-Fordjour et al. (2009). It has frequently been suggested that in epiphytes, density and richness are driven by environmental conditions such as solar radiation (Steege \& Cornelissen, 1989; Werner \& Gradstein, 2009) and different exposure gradients (Théry, 2001). Though, the 'mid-height' peak in epiphyte richness and density (Mucunguzi, 2007) could simply be because of fluctuating available physical support rather than changes in climate regimes (Hietz \& Hietz-Seifert, 1995; Sillett \& Bailey, 2003). Most studies that investigated the distribu- 
Table 8 Spearman's rank correlation coefficient for the D.R.C.

\begin{tabular}{lcclcccr}
\hline & Axis 1 & Axis 2 & DBH & Height & Area & pH & No. branches \\
\hline Axis 1 & 1 & & & & & \\
Axis 2 & -0.15 & 1 & & & & \\
DBH & $\mathbf{0 . 6 4 4}$ & -0.168 & 1 & & & \\
Height & 0.402 & -0.387 & $\mathbf{0 . 4 7 2}$ & 1 & & 1 \\
Area & $\mathbf{0 . 6 6 6}$ & -0.226 & 0.96 & $\mathbf{0 . 6 6 9}$ & 1 & \\
pH & -0.097 & 0.288 & 0.156 & -0.043 & 0.131 & $\mathbf{0 . 6 2 4}$ & -0.003 \\
No. branches & $\mathbf{0 . 9 0 3}$ & 0.069 & $\mathbf{0 . 6 0 5}$ & 0.279 & & 1 \\
\hline
\end{tabular}

The critical value for a two-tailed $r_{\mathrm{s}}$ at $\alpha 0.05$ was 0.447 . Significant values are given in bold.

Table 9 Spearman's rank correlation coefficient for Zambia

\begin{tabular}{|c|c|c|c|c|c|c|c|}
\hline & Axis 2 & Axis 3 & DBH & Height & Area & $\mathrm{pH}$ & No. branches \\
\hline Axis 2 & 1 & & & & & & \\
\hline Axis 3 & 0.002 & 1 & & & & & \\
\hline $\mathrm{DBH}$ & -0.005 & 0.286 & 1 & & & & \\
\hline Height & 0.197 & 0.177 & 0.417 & 1 & & & \\
\hline Area & 0.075 & 0.266 & 0.942 & 0.674 & 1 & & \\
\hline $\mathrm{pH}$ & -0.413 & -0.365 & -0.017 & -0.211 & -0.096 & 1 & \\
\hline No. branches & 0.177 & -0.441 & -0.089 & 0.141 & 0.008 & 0.026 & 1 \\
\hline
\end{tabular}

The critical value for a two-tailed $r_{\mathrm{s}}$ at $\alpha 0.05$ was 0.447 . Significant values are given in bold.

tion of epiphytes (Normann et al., 2010) mostly ignored area as a factor in explaining epiphyte richness and density (Rodrigode, Borgo \& Menezes, 2009), and others found only small effects (Löbel, Snäll \& Rydin, 2006). In this study, surface area seems to be of high importance and was strongly correlated to species density and richness but explained only a small fraction of the variation in the data. These highlight how important other factors than area are. Orchids, for example, had their highest density in zone 3 , as compared to the other groups that had their highest densities in zone 4 (Fig. 3). Orchids are known for their sensitivity to high solar exposure and their desiccation intolerances (Benzing, 1990; Lowman \& Rinker, 2004). Epiphytes, as most plants, can only exploit available resources outside their current realized niche when conditions are most favourable. Any differences in their niche optima need to be avoided by the epiphyte.

The aspect of the branch, the slope and the roughness of the bark are thought to be often important factors in shaping epiphyte communities within phorophytes (Marmor, Tõrra \& Randlane, 2010; Nadkarni, 1994; Affeld et al., 2008). Tree bark in particular is one of the most commonly used substrates of epiphytes and can affect the epiphyte's ability to establish, attach and grow. Many studies have shown that different bark traits such as texture and $\mathrm{pH}$ affect epiphyte richness and composition (Wyse \& Burns, 2011). Lightly and deeply fissured bark accommodates often more species and higher densities of epiphytes because bark with deeper fissures provides a better 'holding surface' for epiphytes. Flaky bark on the other hand does not support many epiphytes because of the instability of the substrate. For both sample sites, bark texture, however, was not significantly correlated to epiphyte richness and density (Tables 8 and 9). This is not surprising given that most branches had lightly fissured bark $(83.3 \%)$, which weakened the effect of bark texture on the epiphyte.

On both sites, epiphyte richness showed significant correlation with branch aspect (Tables 8 and 9). Branches at the Zambian site showed a positive significant correlation and branches at the D.R.C. site a negative significant correlation with species richness. In Zambia, epiphytes had a higher richness on north-west-facing branches, and in the D.R.C., epiphyte richness was highest on north-east-facing branches. Moreover, on both sites, richness was lowest on north-facing branches. The low 
species richness on north-facing branches could be the result of different stress conditions (Steege \& Cornelissen, 1989) in terms of exposure differences. Annual mean solar radiation is strongest from the north (Tukiainen, 2012) and could therefore explain the difference in observed species richness. Other branches provide possibly better growing conditions to epiphytes; however, detailed data are lacking.

It is clear that epiphytes are less diverse in dry woodlands when compared to tropical forest. However, they account for an important proportion of the African epiphyte flora, with many species still being discovered (Fischer, Killmann \& Lebel, 2009; Fischer et al., 2010). Groups of epiphytes show a clear pattern of zonation, where density and species richness increased with height in the canopy. These changes are mainly associated with the size of the host, with larger trees hosting more epiphytes. Although the number of phorophytes under investigation was relatively low, this study provides an important baseline against which future changes can be monitored. Understanding the relationships between epiphytes and their host trees will be of fundamental importance in future conservation efforts regarding dry woodland management in Africa.

\section{Acknowledgements}

I would like to thank Dr. Tariq Stévart from the Herbarium de l'Universté Libre de Bruxelles, Vincent Droissart from the Institut de Recherche pour le Développement (IRD)/Botanique et Bioinformatique de l'Architecture des Plantes, Phillip J. Cribb from the Royal Botanical Garden Kew and Emile Kizmba Kibuye from the Université de Lubumbashi for their help to identify some of the Orchidaceae specimens. Furthermore, I gratefully acknowledge Dr. Alain Vanderpoorten from Liège University, Belgium, and Jo Wilbraham from the Natural History Museum in London for the Bryophyte identification. In addition, I would thank Felix Chileshe of the Forestry Department in Kitwe, Zambia, the Nsobe Game Park/Miengwe Farm Ltd., Zambia and African Mining Consultants (AMC) Mining and Environmental Engineering. I also would like to thank Dr. Stephen Burchett (University of Plymouth) for his supervision and further Angela Duerden, Stephan Batke, Ben Waterhouse, Luke Holmes, Damian Hess and Mpande Sichamba for their support. Finally, I thank Steven Duerden for his help with the data collection.

\section{References}

Addo-Fordjour, P., Anning, A.K., Addo, M.G. \& Osei, M.F. (2009) Composition and distribution of vascular epiphytes in a tropical semideciduous forest, Ghana. Afr. J. Ecol. 47, 767-773.

Affeld, K., Sullivan, J., Worner, S.P. \& DidHam, R.K. (2008) Can spatial variation in epiphyte diversity and community structure be predicted from sampling vascular epiphytes alone? J. Biogeogr. 35, 2274-2288.

AkinsoJi, A. (1990) Studies on epiphytic flora of a tropical rain forest in southwestern Nigeria: I: the vascular epiphytes. Vegetatio 88, 87-92.

Barthelemy, D. (1992) Essai de caracterisation des successions d'epiphytes non vasculaires et de leur role dans la mise en place des epiphytes vasculaires. Mission radeau des cimes. Foundation Elf, Campo, Cameroun. In: Epiphyte Diversity in Primary and Fragmented Forest of Cameroon, Central Africa: A Preliminary Survey (Eds B.A. NKongmeneck, M.D. Lowman and J.T. Aтwoon). Selbyana, Yaounde, West Africa, 23, pp. 121-130.

BAтKE, S. (2012) Epiphytes: a study of the history of forest canopy research. The Plymouth Student Scientist 5, 253-268.

BenZING, D.H. (1987) Vascular epiphytism: taxonomic participation and adaptive diversity. Ann. Mo. Bot. Gard. 74, 183-204.

BenZING, D.H. (1990) Vascular Epiphytes - General Biology and Related Biota. Cambridge University Press, Cambridge.

BIEDINGER, N. \& FisChER, E. (1996) Epiphytic vegetation and ecology in central African Forest (Rwanda, Zaïre). Ecotropica 2, 121-142.

Callaway, R.M., Reinhart, K.O., Moore, G.W., Moore, J.M. \& Pennings, S.C. (2002) Epiphyte host preferences and host traits: mechanisms for species-specific interactions. Oecologia 132, 221-230.

Chidumayo, E.N. \& Gumbo, D.J. (2010) The Dry Forests and Woodlands of Africa. Earthscan, Washington, DC

DAVIDSON, D.W. (1988) Ecological studies of neotropical ant gardens. Ecology 69, 1138-1152.

Díaz, I.A., Sieving, K.E., Peña-Foxon, M.E., Larraín, J. \& Armesto, J.J. (2010) Epiphyte diversity and biomass loads of canopy emergent trees in Chilean temperate rain forests: a neglected functional component. For. Ecol. Manage. 259, 1490-1501.

Droissart, V., Hardy, O.J., SonkÉ, B., Dahdouh-Guebas, F. \& STÉVART, T. (2012) Subsampling herbarium collections to assess geographic diversity gradients: a case study with endemic Orchidaceae and Rubiaceae in Cameroon. Biotropica 44, 44-52.

Droissart, V., Sonké, B., Hardy, O., Simo, M., Taedoumg, H., Nguembou, C. \& STÉvarT, T. (2011) Do plant families with contrasting functional traits show similar patterns of endemism? A case study with Central African Orchidaceae and Rubiaceae. Biodivers. Conserv. 20, 1507-1531. 
Fischer, E.A. \& Araujo, A.C. (1995) Spatial organization of a bromeliad community in the Atlantic rainforest, south-eastern Brazil. J. Trop. Ecol. 11, 559-567.

Fischer, E., Killmann, D. \& Lebel, J.P. (2009) Polystachya bruechertiae, eine neue Art aus dem Cyamudongo-Wald, Ruanda - Polystachya bruechertiae, a new species from Cyamudongo Forest, Rwanda. Die Orchidee 60, 104-113.

Fischer, E., Killmann, D., Lebel, J.P. \& Delepierre, G. (2010) Polystachya samilae - eine neue Art aus dem Nyungwe Nationalpark, Ruanda - Polystachya samilae - a new species from Nyungwe National Park, Rwanda. Die Orchidee 61, 240244.

FRITZ, Ö. (2009) Vertical distribution of epiphytic bryophytes and lichens emphasizes the importance of old beeches in conservation. Biodivers. Conserv. 18, 289-304.

GauslaA, Y., Lie, M. \& Ohlson, M. (2008) Epiphytic lichen biomass in a boreal Norway spruce forest. Lichenologist 40 , 257-266.

GENTRY, A.H. (1982) Neotropical floristic diversity: phytogeographical connections between Central and South America, pleistocene climatic fluctuations, or an accident of the andean orogeny? Ann. Mo. Bot. Gard. 69, 557-593.

Gradstein, S.R., NAdKarni, N.M., KröMer, T., Holz, I. \& NöSKe, N. (2003) A protocol for rapid and representative sampling of vascular and non-vascular epiphyte diversity of tropical rain forests. Selbyana 24, 105-111.

HEMP, A. (2006) Continuum or zonation? Altitudinal gradients in the forest vegetation of Mt. Kilimanjaro. Plant Ecol. 184, 27-42.

Hietz, P. \& HiETz-Seifert, U. (1995) Structure and ecology of epiphyte communities of a cloud forest in central Veracruz, Mexico. J. Veg. Sci. 6, 719-728.

Hsu, C.-C., Horng, F.-W. \& Kuo, C.-M. (2002) Epiphyte biomass and nutrient capital of a moist subtropical forest in northeastern Taiwan. J. Trop. Ecol. 18, 659-670.

INPL (2010) Kamoa Copper Project - NI 43-101 Technical Report. Ivanhoe Nickel and Platinum Ltd., Democratic Republic of Congo.

JoHAnsson, D. (1974) Ecology of vascular epiphytes in West African rain forest. Acta Phytogeogr. Suec. 59, 1-136.

JoHANSSON, D.R. (1978) A method to register the distribution of epiphytes on the host tree. Amer. Orchid Soc. Bull. 47, 901-904.

Kent, M. (2012) Vegetation Description and Data Analysis. Wiley-Blackwell, Singapore.

Kress, W.J. (1986) The systematic distribution of vascular epiphytes: an update. Selbyana 9, 2-22.

KüRSCHNER, H. (1995) Epiphytische Moosgesellschaften im östlichen Kongobecken und den angrenzenden Gebirgsstöcken (Parc National de Kahuzi-Biega/Zaire, Forêt de Nyungwe/ Rwanda). Wissenschaftliche Ergebnisse der BRYOTROPExpedition nach Zaire und Rwanda Nr. 4. Nova Hedwigia 61, $1-64$.

LÖBEL, S. \& RYDIN, H. (2009) Dispersal and life history strategies in epiphyte metacommunities: alternative solutions to survival in patchy, dynamic landscapes. Oecologia 161, 569-579.
LÖBEL, S., SNÄLL, T. \& RYDIN, H. (2006) Species richness patterns and metapopulation processes - evidence from epiphyte communities in boreo-nemoral forests. Ecography 29, 169-182.

LOWMAN, M.D. \& RiNKER, H.B. (2004) Forest Canopies. Elsevier Academic Press, Burlington, VT, USA.

Marmor, L., Tõrra, T. \& Randlane, T. (2010) The vertical gradient of bark $\mathrm{pH}$ and epiphytic macrolichen biota in relation to alkaline air pollution. Ecol. Ind. 10, 1137-1143.

Mccune, B. \& MefFord, M.J. (2011) PC-ORD Multivariate Analysis of Ecological Data. 6.0 ed. MjM Software, OR.

Minitab, Inc. (2010) Minitab. 16.1.0.0 ed. Minitab Inc., State College, PA.

Mucunguzi, P. (2007) Diversity and distribution of vascular epiphytes in the forest lower canopy in Kibale National Park, western Uganda. Afr. J. Ecol. 45, 120-125.

Muñoz, A.A., Chacon, P., Perez, F., Barnert, E.S. \& Armesto, J.J. (2003) Diversity and host tree preferences of vascular epiphytes and vines in a temperate rainforest in southern Chile. Aust. J. Bot. 51, 381-391.

NADKARNI, N.M. (1994) Diversity of species and interaction in the upper tree canopy of forest ecosystems. Amer. Zool. 34, $70-78$.

NADKARNi, N.M. \& MAtelson, T.J. (1989) Bird use of epiphyte resources in neotropical trees. Condor 91, 891-907.

NKongmeneck, B.A., Lowman, M.D. \& Atwood, J.T. (2002) Epiphyte diversity in primary and fragmented forest of Cameroon, Central Africa: a preliminary survey. Selbyana 23 , 121-130.

Normann, F., Weigelt, P., Gehrig-Downie, C., Gradstein, S.R., Sipman, H.J.M., Obregon, A. \& Bendix, J. (2010) Diversity and vertical distribution of epiphytic macrolichens in lowland rain forest and lowland cloud forest of French Guiana. Ecol. Ind. 10, 1111-1118.

NyANDWI, E. (2008) Road edge effect on Forest Canopy structure and Epiphyte biodiversity in a Tropical Mountainous Rainforest, Nyungwe National Park, Rwanda. International Institute for Geo-Information Science and Earth Observation Enschede, the Netherlands.

PhIRI, P.S.M. (2005) A Checklist of Zambian Vascular Plants Report 32. Southern African Botanical Diversity Network, Pretoria.

PIKE, L.H. (1978) The importance of epiphytic Lichens in mineral cycling. Bryologist 81, 247-257.

Poulsen, A.D., Hafashimana, D., Eilu, G., Liengola, I.B., Ewango, C.R.N. \& HART, T.B. (2005) Composition and species richness of forest plants along the Albertine rift. Africa. Biol. Skr. 55, 129-143.

Purvis, W. (2000) Lichens. Natural History Museum, London.

Rodrigode, A.K., Borgo, M. \& Menezes, S.S. (2009) Diversity and distribution of vascular epiphytes in an insular Brazilian coastal forest. Rev. Biol. Trop. 57, 749-759.

SANFORD, W.W. (1968) Distribution of epiphytic orchids in semideciduous tropical forest in southern Nigeria. J. Ecol. 56, 697705 . 
SANFORD, W.W. (1969) The distribution of epiphytic orchids in Nigeria in relation to each other and to geographic location and climate, type of vegetation and tree species. Biol. J. Linn. Soc. 1, 247-285.

SchaIJes, M. \& Malaisse, F. (2001) Diversity of upper Katanga epiphytes (mainly orchids) and distribution in different vegetation units. Syst. Geogr. Plants 71, 575-584.

Schuettpelz, E. \& TrapnelL, D.W.T. (2006) Exceptional epiphyte diversity on a single tree in Costa Rica. Selbyana 27 $65-71$.

SERMoLLi, R.E.G.P. (1985) A contribution to the knowledge of the Pteridophyta of Rwanda, Burundi, and Kivu (Zaire). II. Bull. Jard. Bot. Nat. Belg. 55, 123-206.

SiLleTt, S.C. \& ANToine, M.E. (2004) Lichens and bryophytes in forest canopies. In: Forest Canopies, 2nd edn (Eds M.D. Lowman and H.B. Rinker). Elsevier Academic Press, London. Sillett, S.C. \& Bailey, M.G. (2003) Effects of tree crown structure on biomass of the epiphytic fern Polypodium scouleri (Polypodiaceae) in Redwood forests. Am. J. Bot. 90, 255-261.

Steege, H.T. \& CoRnelissen, J.H.C. (1989) Distribution and ecology of vascular epiphytes in lowland rain forest of Guyana. Biotropica 21, 331-339.

SWANK, W.T. \& SchreudER, H.T. (1974) Comparison of three methods of estimating surface area and biomass for a forest of young eastern white pine. For. Sci. 20, 91-100.

THÉRY, M. (2001) Forest light and its influence on habitat selection. Plant Ecol. 153, 251-261.

TukiAinEn, M. (2012) Gaisma. Available at: www.gaisma.com (accessed January 3 2012).
Velleman, P. \& John, C. (1996) Data Desk (Windows). 6.1 ed. Data Description Inc., New York.

Werner, F. \& GRADSTEIN, S. (2008) Seedling establishment of vascular epiphytes on isolated and enclosed forest trees in an Andean landscape, Ecuador. Biodivers. Conserv. 17, 3195-3207.

WERnER, F.A. \& GRAdSTEIn, S.R. (2009) Diversity of dry forest epiphytes along a gradient of human disturbance in the tropical Andes. J. Veg. Sci. 20, 59-68.

WoLf, J.H.D. (1994) Factors controlling the distribution of vascular and non-vascular epiphytes in the Northern Andes. Vegetatio 112, 15-28.

WoLF, J.H.D. (2005) The response of epiphytes to anthropogenic disturbance of pine-oak forests in the highlands of Chiapas, Mexico. For. Ecol. Manage. 212, 376-393.

WYSE, S.V. \& BuRNS, B.R. (2011) Do host bark traits influence trunk epiphyte communities? New Zeal. J. Ecol. 35, 296-301.

ZAPFACK, L. \& ENGWALD, S. (2008) Biodiversity and spatial distribution of vascular epiphytes in two biotopes of the Cameroonian semi-deciduous rain forest. Plant Ecol. 195. 117-130.

Zapfack, L., Nkongmeneck, B.A., Villiers, J.F. \& Lowman, M.D. (1996) The importance of pteridophytes in the epiphytic flora of some phorophytes of the Cameroonian semi-deciduous rain forest. Selbyana 17, 76-81.

(Manuscript accepted 27 February 2012)

doi: 10.1111/j.1365-2028.2012.01330.x 